ISSN 0258-7122

Bangladesh J. Agril. Res. 35(3) : 475-488, September 2010

\title{
QUALITY OF TOMATO (Lycopersicon esculentum Mill.) AS INFLUENCED BY BORON AND ZINC UNDER DIFFERENT LEVELS OF NPK FERTILIZERS
}

\author{
M.A. SALAM ${ }^{1}$, M.A. SIDDIQUE ${ }^{2}$, M.A. RAHIM ${ }^{3}$ \\ M. A. RAHMAN ${ }^{4}$ AND M.G. SAHA ${ }^{5}$
}

\begin{abstract}
The study was conducted at the vegetable research farm of the Horticulture Research Centre, Bangladesh Agricultural Research Institute, Joydebpur, Gazipur during the period 2006-2007 to investigate the effects of boron and zinc in presence of different levels of NPK fertilizers on quality of tomato. There were twelve treatment combinations which comprised four levels of boron and zinc viz., i) $\mathrm{B}_{0} \mathrm{Zn}_{0}=0 \mathrm{~kg} \mathrm{~B}+0 \mathrm{~kg} \mathrm{Zn} / \mathrm{ha}$, ii) $\mathrm{B}_{1.5} \mathrm{Zn}_{2.0}=1.5 \mathrm{~kg} \mathrm{~B}+2.0 \mathrm{~kg} \mathrm{Zn} / \mathrm{ha}$, iii) $\mathrm{B}_{2.0} \mathrm{Zn}_{4.0}=2.0 \mathrm{~kg} \mathrm{~B}+4.0 \mathrm{~kg} \mathrm{Zn} / \mathrm{ha}$, iv) $\mathrm{B}_{2.5} \mathrm{Zn}_{6.0}, 2.5 \mathrm{~kg} \mathrm{~B}+6.0 \mathrm{~kg} \mathrm{Zn} / \mathrm{ha}$ and three levels of NPK fertilizers viz., i) 50\% less than the recommended NPK fertilizer dose (50\% <RD), ii) Recommended NPK fertilizer dose (RD), iii) 50\% more than the recommended NPK fertilizer dose $(50 \%>\mathrm{RD})$. The highest pulp weight $(88.14 \%)$, dry matter content $(5.34 \%)$, TSS $(4.50 \%)$, acidity $(0.47 \%)$, ascorbic acid (10.95 mg/100g), lycopene content $(112.00 \mu \mathrm{g} / 100 \mathrm{~g})$, chlorophylla $(41.00 \mu \mathrm{g} / 100 \mathrm{~g})$, chlorophyll-b $(56.00 \mu \mathrm{g} / 100 \mathrm{~g})$, marketable fruits at 30 days after storage (67.48\%) and shelf life (16 days) were recorded with the combination of $2.5 \mathrm{~kg} \mathrm{~B}+6 \mathrm{~kg} \mathrm{Zn} / \mathrm{ha}$ and recommended dose of NPK fertilizers $(\mathrm{N}=253, \mathrm{P}=90$, and $\mathrm{K}=125 \mathrm{~kg} / \mathrm{ha})$.
\end{abstract}

Keywords: Quality of tomato, boron and zinc, NPK fertilizer.

\section{Introduction}

Tomato (Lycopersicon esculentum Mill.) is one of the most important and popular vegetables in Bangladesh. It ranks third in the world's vegetable production, next to potato and sweet potato, placing itself first as processing crop among the vegetables. It is a cheap source of vitamin-C and minerals. Tomato covers about $9.80 \%$ of the area under total winter vegetables in Bangladesh and its yield was $06.98 \mathrm{t} / \mathrm{ha}$ in the country during the year 2005-06 (BBS, 2007). Adequate supply of nutrient can increase the yield, fruit quality, fruit size, keeping quality, colour and taste of tomato (Shukla and Naik. 1993). Micronutrients also play an important role in tomato production. Among the micro elements, boron and zinc play an important role directly and indirectly in improving the yield and quality of tomato in addition to checking various diseases and physiological disorders (Magalhaes et al., 1980). Boron affects the

\footnotetext{
${ }^{1}$ Senior Scientific Officer, HRC, Bangladesh Agricultural Research Institute (BARI), Gazipur, ${ }^{2,384}$ Professor, Department of Horticulture, Bangladesh Agricultural University (BAU), Mymensingh, ${ }^{5}$ Principal Scientific Officer, HRC, Bangladesh Agricultural Research Institute (BARI,) Gazipur, Bangladesh.
} 
quality of tomato fruit, particularly size and shape, colour, smoothness, firmness, keeping quality and chemical composition. Demoranville and Deubert (1987) reported that fruit shape, yield, and shelf life of tomato were also affected by boron nutrition. Zinc plays an important role in chlorophyll formation, cell division, meristematic activity of tissue expansion of cell and formation of cell wall. Zinc application also helps in increasing the uptake of nitrogen and potash. Application of zinc sulphate, copper sulphate and ammonium molybdate stimulates chlorophyll synthesis and fruit quality of tomato (Kalloo, 1985). Kumar 2003) reported that application of FYM $25 \mathrm{t} / \mathrm{ha}+150 \%$ NPK (150:112:82.5 kg/ha NPK) in tomato was the best for obtaining higher values in respect of growth, yield, and quality of tomato.

In order to improve the quality of tomato, there should have the technologies which will eventually fulfill the grower's as well as consumer's need. Studies on management practices, particularly on the management of boron and zinc would help increasing quality of tomato. Available information on the stated subject under Bangladesh conditions is inadequate. The present investigation was, therefore, carried out with a view to observing the influence of boron and zinc under different levels of $\mathrm{N}, \mathrm{P}$, and $\mathrm{K}$ on the quality of tomato.

\section{Materials and Method}

The experiment was carried out at the vegetable research farm of the Horticulture Research Centre, BARI during the period from October 2006 to March 2007. The soil of the experimental plot falls under Madhupur tract (AEZ-28) characterized by high clay and low $\mathrm{p}^{\mathrm{H}}$ (6.4). The soil contained $1.64 \%$ organic matter, total nitrogen $0.087 \%$, available phosphorus $29 \mu \mathrm{g} / \mathrm{ml}, 0.11 \mathrm{meq} / 100 \mathrm{~g}$ of soil exchangeable potassium, $0.22 \mu \mathrm{g} / \mathrm{ml}$ boron and $1.8 \mu \mathrm{g} / \mathrm{ml}$ zinc. The study consisted of four levels of boron and zinc viz., i) $\mathrm{B}_{0} \mathrm{Zn}_{0}=0 \mathrm{~kg} \mathrm{~B}+0 \mathrm{~kg} \mathrm{Zn} / \mathrm{ha}$, ii) $\mathrm{B}_{1.5} \mathrm{Zn}_{2.0}=1.5 \mathrm{~kg} \mathrm{~B}+2.0 \mathrm{~kg} \mathrm{Zn} / \mathrm{ha}$, iii) $\mathrm{B}_{2.0} \mathrm{Zn}_{4.0}=2.0 \mathrm{~kg} \mathrm{~B}+4.0 \mathrm{~kg} \mathrm{Zn} / \mathrm{ha}$, iv) $\mathrm{B}_{2.5} \mathrm{Zn}_{6.0}=2.5 \mathrm{~kg} \mathrm{~B}+6.0 \mathrm{~kg} \mathrm{Zn} / \mathrm{ha}$ and three levels of NPK fertilizers viz., i) $50 \%(1 / 2)$ of the recommended NPK fertilizer dose, ii) Recommended NPK fertilizer dose (RD), and iii) 150\% (1.5 times) of the recommended NPK fertilizer dose. The recommended doses of NPK fertilizers for tomato are $550 \mathrm{~kg}$ urea, $450 \mathrm{~kg}$ TSP, $250 \mathrm{~kg} \mathrm{MoP} / \mathrm{ha}$ (BARI, 2004). Thus, there were 12 treatment combinations $(4 \times 3)$ in the experiment. In addition to the levels of boron and zinc and NPK under investigation, $10 \mathrm{t}$ cow dung, and $120 \mathrm{~kg}$ gypsum per hectare were applied. The sources of boron and zinc were boric acid and zinc oxide, respectively. The experiment was laid out in a RCB design with three replications. The unit plot was $2.4 \mathrm{~m} \times 2.4 \mathrm{~m}$. Two adjacent unit plots were separated by $70 \mathrm{~cm}$ and $01 \mathrm{~m}$ space was given between the blocks. Half of the quantity of cow dung, the entire quantity of TSP, gypsum and 1/3 MoP were applied during final land preparation. The remaining cow dung, entire boron, and 
zinc were applied during pit preparation. The entire urea and the rest of MoP were applied in three equal installments at 15, 30, and 50 days after transplanting. BARI Tomato-9 was used in this experiment. Healthy and uniform sized 30 days old seedlings were transplanted at $60 \mathrm{~cm} \times 40 \mathrm{~cm}$ spacing on 15 November 2006 . Inter cultural operations were done as and when needed. Data were collected on number of filled seeds per fruit, pulp weight (expressed in percent on weight basis), dry matter content, total soluble solid (TSS), acidity (Rangana, 1994), ascorbic acid, lycopene content, chlorophyll-a and chlorophyll-b according to Nagata et al. (1992), boron content (Hunter, 1980), zinc content (Rahayu et al., 2001), percent weight loss, percent marketable fruit and shelf life (Mondal, 2000). From the middle rows of each plot, middle six plants were selected to record data. Recorded data were analyzed statistically and means were compared by the Least Significant Difference (LSD) test.

\section{Results and Discussion}

Number of filled seeds per fruit: The number of filled seeds produced per plant was counted to see the seed production potentialities under the study. Boron and zinc levels showed wide variation regarding this parameter. It ranged from 81.33 to 92.66 (Table 1). Distinct difference was found as to the number of filled seeds per fruit due to the main effect of NPK. It was as low as 86.00 in $50 \%$ less than recommended dose of NPK to as high as 90.25 in recommended dose of NPK (Table 2). On the other hand, combination of boron, zinc, and NPK reflected marked variation as to the number of filled seeds per fruit. The maximum filled seeds per fruit (96.00) was found with $2.5 \mathrm{~kg} \mathrm{~B}+6 \mathrm{~kg} \mathrm{Zn/ha} \mathrm{and} \mathrm{recommended}$ dose of NPK, followed by $2 \mathrm{~kg} \mathrm{~B}+4 \mathrm{~kg} \mathrm{Zn/ha}$ and recommended dose of NPK (94.00), whereas it was significantly the lowest (79.00) without boron, zinc and $50 \%$ less than recommended dose of NPK (Table 3). The reason for higher number of filled seeds per fruit may be due to increase in photosynthate rate and translocation of food material to seed. Kumari (2005) suggested that $100 \mathrm{ppm}$ boron spray at 30 days after transplanting and repeated at 10 days interval in tomato cv. Solan Vajr could result in maximum seed yield.

Pulp weight: Boron and zinc levels had marked influence on this trait. It was observed that pulp weight increased with an increasing boron and zinc levels. It varied from 74.04 to $82.51 \%$ (Table 1 ). Pulp weight was greatly affected by NPK. It was the maximum (81.82\%) in recommended dose of NPK and the minimum (73.81\%) in $50 \%$ less than recommended dose of NPK (Table 2). On the other hand, there was a significant difference among the treatment combinations as to the pulp weight of the fruit. It ranged from 70.00 to $88.14 \%$ (Table 3). The highest pulp weight (88.14\%) was recorded from the plants produced with $2.5 \mathrm{~kg} \mathrm{~B}+6 \mathrm{~kg} \mathrm{Zn/ha}$ and recommended dose of NPK followed by $2.5 \mathrm{~kg} \mathrm{~B}+6 \mathrm{~kg} \mathrm{Zn/ha} \mathrm{and} \mathrm{50 \%} \mathrm{more} \mathrm{than} \mathrm{recommended} \mathrm{dose} \mathrm{of} \mathrm{NPK}$ 
Table 1. Main effect of boron and zinc on fruit quality of tomato.

\begin{tabular}{|c|c|c|c|c|c|c|c|c|c|c|c|}
\hline Treatment & $\begin{array}{c}\text { No. of } \\
\text { filled } \\
\text { seeds/fruit }\end{array}$ & $\begin{array}{c}\text { Pulp } \\
\text { wt (\%) }\end{array}$ & $\begin{array}{c}\text { Dry } \\
\text { matter } \\
\text { content } \\
(\%)\end{array}$ & $\begin{array}{l}\text { TSS } \\
(\%)\end{array}$ & $\begin{array}{c}\text { Acidity } \\
\text { (\%) }\end{array}$ & $\begin{array}{c}\text { Ascorbic } \\
\text { acid } \\
(\mathrm{mg} / 100 \mathrm{~g})\end{array}$ & $\begin{array}{l}\text { Lycopene } \\
\text { content } \\
(\mu \mathrm{g} / 100 \mathrm{~g})\end{array}$ & $\begin{array}{c}\text { Chlorophyll-a } \\
(\mu \mathrm{g} / 100 \mathrm{~g})\end{array}$ & $\begin{array}{c}\text { Chlorophyll-b } \\
(\mu \mathrm{g} / 100 \mathrm{~g})\end{array}$ & $\begin{array}{c}\text { Boron } \\
\text { content } \\
\text { (ppm) }\end{array}$ & $\begin{array}{c}\text { Zinc } \\
\text { content } \\
(\mathrm{ppm})\end{array}$ \\
\hline $\mathrm{B}_{0} \mathrm{Zn}_{0}$ & 81.33 & 74.04 & 4.54 & 3.63 & 0.24 & 8.34 & 46.33 & 17.00 & 24.00 & 29.00 & 34.33 \\
\hline $\mathrm{B}_{1.5} \mathrm{Zn}_{2}$ & 85.66 & 76.37 & 4.71 & 3.90 & 0.27 & 8.87 & 69.00 & 28.66 & 39.33 & 30.00 & 39.67 \\
\hline $\mathrm{B}_{2} \mathrm{Zn}_{4}$ & 92.00 & 78.66 & 4.85 & 4.03 & 0.37 & 19.16 & 86.33 & 32.33 & 44.66 & 34.66 & 42.33 \\
\hline$\underline{\mathrm{B}_{2.5} \mathrm{Zn}_{6}}$ & 92.66 & 82.51 & 4.98 & 4.26 & 0.41 & 10.04 & 97.66 & 35.66 & 48.33 & 36.33 & 45.67 \\
\hline LSD (1\%) & 4.63 & 4.21 & 0.16 & 0.54 & 0.026 & 0.38 & 3.13 & 0.87 & 1.23 & 0.89 & 0.82 \\
\hline CV (\%) & 3.94 & 4.08 & 2.35 & 3.65 & 5.65 & 3.17 & 3.09 & 2.03 & 2.22 & 1.78 & 1.43 \\
\hline
\end{tabular}

Table 2. Main effect of NPK on fruit quality of tomato.

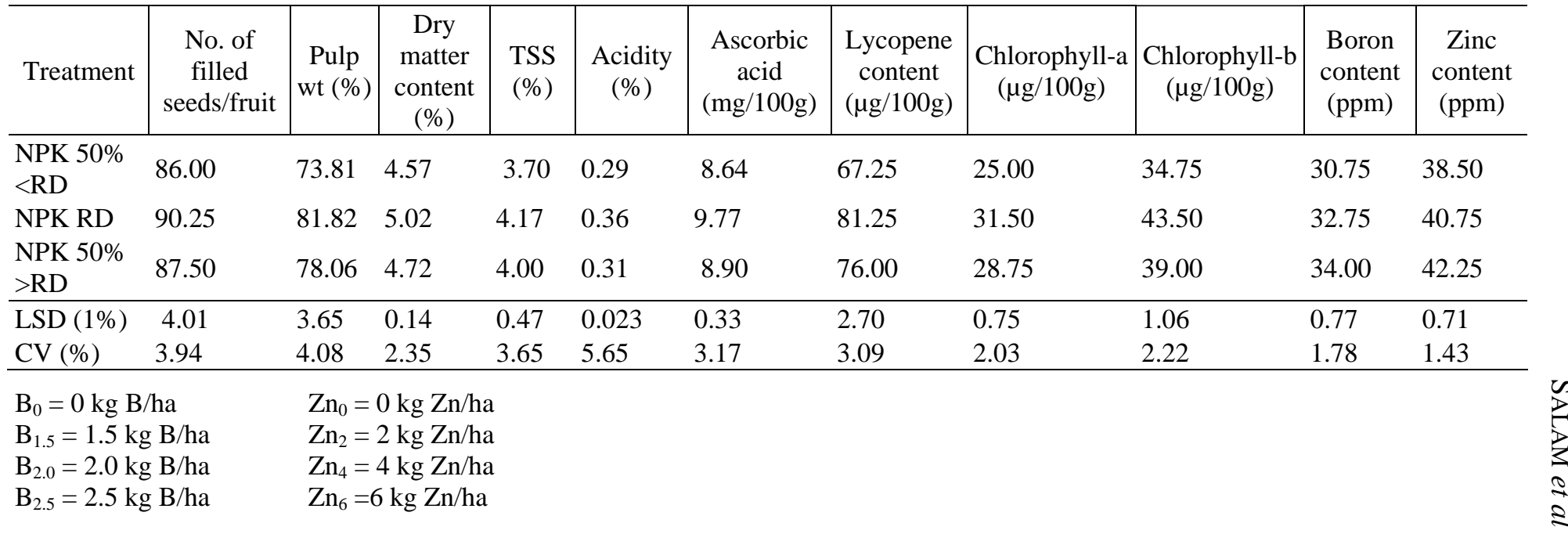


(82.15\%) and $2 \mathrm{~kg} \mathrm{~B}+4 \mathrm{~kg} \mathrm{Zn} / \mathrm{ha}$ and recommended dose of NPK (82.00\%). But the lowest pulp weight was noted from the plants which produced without boron, zinc and $50 \%$ less than recommended dose of NPK, which was statistically significant from other treatment combinations (Table 3). This might be due to higher photosynthet and translocation of food materials to the fruit. Dube et al. (2004) found that the treatment combinations consisting of soil application of zinc sulphate and borax @ 10 and 20 kg/ha, respectively, in combination with their foliar spray @ 0.5 and 0.3 percent, respectively, were found most effective in increasing pericarp thickness

Day matter content: Distinct variation was found in respect of dry matter content of the fruit due to the main effect of boron and zinc. It was as low as $4.54 \%$ without boron and zinc to as high as $4.98 \%$ with $2.5 \mathrm{~kg} \mathrm{~B}+6 \mathrm{~kg} \mathrm{Zn} / \mathrm{ha}$ followed by $2 \mathrm{~kg} \mathrm{~B}+4 \mathrm{~kg} \mathrm{Zn/ha} \mathrm{(4.85 \% )} \mathrm{(Table} \mathrm{1).} \mathrm{Marked} \mathrm{difference} \mathrm{was} \mathrm{noted}$ in this aspect among the NPK levels (Table 2). The highest dry matter content (5.02\%) was recorded from the fruits which were produced with recommended dose of NPK, whereas it was the lowest (4.07\%) with $50 \%$ less than recommended dose of NPK (Table 2). On the contrary, combination of boron, zinc, and NPK showed marked variation as to the dry matter content of the fruit. The highest dry matter (5.34\%) was recorded from the fruits which were produced with $2.5 \mathrm{~kg} \mathrm{~B}+6 \mathrm{~kg} \mathrm{Zn/ha}$ and recommended dose of NPK. The fruits produced without boron, zinc and 50\% less than recommended dose of NPK had less dry matter content (4.40\%), which was statistically significant from the other treatment combinations (Table 3). Balasubramaniam et al. (1998) stated that dry matter content of the stated fruits was favourably influenced by the application of $100 \%$ soil test based NPK combined with borax (10 kg/ha), zinc sulphate (50 $\mathrm{kg} / \mathrm{ha}$ ), and coir pith (5 t/ha).

Total soluble solid (TSS): Total soluble solid content of the fruits varied due to different boron and zinc levels (Table 1). It ranged from 3.63 to 4.26\%. NPK and also had effect on TSS content of the fruits (Table 2). The highest TSS content (4.17\%) was recorded from the fruits which were produced with recommended dose of NPK, whereas it was the lowest (3.70\%) with $50 \%$ less than recommended dose of NPK. Diverse variation was found as to the TSS content of the fruits due to the combination of boron, zinc, and NPK. The highest TSS (4.50\%) was noted with $2.5 \mathrm{~kg} \mathrm{~B}+6 \mathrm{~kg} \mathrm{Zn} / \mathrm{ha}$ and recommended dose of NPK followed by $2.5 \mathrm{~kg} \mathrm{~B}+6 \mathrm{~kg} \mathrm{Zn} / \mathrm{ha}$ and $50 \%$ more than recommended dose of NPK (4.30\%), which was statistically identical. Besides, the lowest TSS content (3.10\%) was recorded from the fruits that were produced without boron, zinc and $50 \%$ less than recommended dose of NPK (Table 3). Puspha (2004) obtained higher total soluble solid with $100 \%$ recommended dose of fertilizers with biofertilizers. 
Table 3. Combined effect of boron and zinc and NPK fertilizers on fruit quality of tomato.

\begin{tabular}{|c|c|c|c|c|c|c|c|c|c|c|c|}
\hline Treatment & \begin{tabular}{|c|} 
No. of \\
filled \\
seeds/fruit
\end{tabular} & $\begin{array}{c}\text { Pulp } \\
\text { wt. (\%) }\end{array}$ & $\begin{array}{c}\text { Dry } \\
\text { matter } \\
\text { content } \\
(\%) \\
\end{array}$ & $\begin{array}{l}\text { TSS } \\
\text { (\%) }\end{array}$ & $\begin{array}{l}\text { Acidity } \\
(\%)\end{array}$ & $\begin{array}{c}\text { Ascorbic } \\
\text { acid } \\
\text { (mg/100g) }\end{array}$ & $\begin{array}{l}\text { Lycopene } \\
\text { content } \\
(\mu \mathrm{g} / 100 \mathrm{~g})\end{array}$ & $\begin{array}{l}\text { Chlorophyll-a } \\
\text { ( } \mu \mathrm{g} / 100 \mathrm{~g})\end{array}$ & $\begin{array}{l}\text { Chlorophyll-b } \\
\text { ( } \mu \mathrm{g} / 100 \mathrm{~g})\end{array}$ & $\begin{array}{c}\text { Boron } \\
\text { content } \\
(\mathrm{ppm})\end{array}$ & $\begin{array}{c}\text { Zinc } \\
\text { content } \\
(\mathrm{ppm})\end{array}$ \\
\hline $\begin{array}{l}\mathrm{B}_{0} \mathrm{Zn}_{0} \mathrm{NPK} \\
50 \%<\mathrm{RD}\end{array}$ & 79.00 & 70.00 & 4.40 & 3.10 & 0.24 & 8.00 & 41.00 & 16.00 & 24.00 & 28.00 & 33.00 \\
\hline $\mathrm{B}_{0} \mathrm{Zn}_{0}$ NPK RD & 84.00 & 77.14 & 4.70 & 4.00 & 0.26 & 8.92 & 51.00 & 18.00 & 25.00 & 29.00 & 35.00 \\
\hline $\begin{array}{l}\mathrm{B}_{0} \mathrm{Zn}_{0} \mathrm{NPK} \\
50 \%>\mathrm{RD}\end{array}$ & 81.00 & 75.00 & 4.52 & 3.80 & 0.24 & 8.10 & 47.00 & 17.00 & 23.00 & 30.00 & 35.00 \\
\hline $\begin{array}{l}\mathrm{B}_{1.5} \mathrm{Zn}_{2} \mathrm{NPK} \\
\mathrm{RD}\end{array}$ & 87.00 & 80.00 & 5.00 & 4.00 & 0.30 & 9.35 & 71.00 & 31.00 & 42.00 & 30.00 & 40.00 \\
\hline $\begin{array}{l}\mathrm{B}_{1.5} \mathrm{Zn}_{2} \mathrm{NPK} \\
50 \%>\mathrm{RD}\end{array}$ & 86.00 & 76.11 & 4.65 & 3.90 & 0.27 & 8.81 & 69.00 & 30.00 & 41.00 & 32.00 & 41.00 \\
\hline $\begin{array}{l}\mathrm{B}_{2} \mathrm{Zn}_{4} \mathrm{NPK} \\
50 \%<\mathrm{RD}\end{array}$ & 91.00 & 75.00 & 4.71 & 3.90 & 0.33 & 8.72 & 80.00 & 28.00 & 38.00 & 33.00 & 41.00 \\
\hline $\begin{array}{l}\mathrm{B}_{2.5} \mathrm{Zn}_{6} \mathrm{NPK} \\
\mathrm{RD}\end{array}$ & 96.00 & 88.14 & 5.34 & 4.50 & 0.47 & 10.95 & 112.00 & 41.00 & 56.00 & 37.00 & 46.00 \\
\hline $\begin{array}{l}\mathrm{B}_{2.5} \mathrm{Zn}_{6} \mathrm{NPK} \\
50 \%>\mathrm{RD}\end{array}$ & 92.00 & 82.15 & 4.93 & 4.30 & 0.40 & 9.78 & 100.00 & 35.00 & 47.00 & 38.00 & 49.00 \\
\hline LSD (1\%) & 8.02 & 7.30 & 0.28 & 0.94 & 0.046 & 0.67 & 5.41 & 1.51 & 2.13 & 1.54 & 1.43 \\
\hline CV (\%) & 3.94 & 4.08 & 2.35 & 3.65 & 5.65 & 3.17 & 3.09 & 2.03 & 2.22 & 1.78 & 1.43 \\
\hline
\end{tabular}


Acidity: Acidity is an important factor for canning of fruits. High acidity is better for canning performance. Considering the main effect of boron and zinc, acidity was significantly influenced. Acidity content of the fruits increased with the increasing boron and zinc levels (Table 1). NPK also had significant effect on this trait (Table 2). It ranged from 0.29 to $0.36 \%$. On the other hand, distinct variation was observed among the treatment combinations as to the acidity content of the fruits. The results of the investigation reflected that acidity content of the fruits increased upto recommended dose of NPK and then decreased irrespective of boron and zinc levels (Table 3$)$. The highest acidity $(0.47 \%)$ was found in fruits which were produced with $2.5 \mathrm{~kg} \mathrm{~B}+6 \mathrm{~kg} \mathrm{Zn/ha}$ and recommended dose of NPK followed by $2 \mathrm{~kg} \mathrm{~B}+4 \mathrm{~kg} \mathrm{Zn/ha} \mathrm{and} \mathrm{recommended}$ dose of NPK $(0.45 \%)$. On the contrary, the fruits produced without boron, zinc and $50 \%$ less than recommended dose of NPK had the lowest acidity content (0.24\%). Huang and Snapp (2004) noted the highest titratable acidity with $2 \mathrm{~kg}$ boron per hectare. On the other hand, Puspha (2004) obtained the highest titratable acidity under 100 percent recommended dose of fertilizers with biofertilizers.

Ascorbic acid: Ascorbic acid is an important vitamin to human health. Its requirement is $30 \mathrm{mg}$ per day for normal growth and development. Marked difference was observed as to the ascorbic acid content of the fruit due to the boron and zinc levels. The highest ascorbic acid $(10.04 \mathrm{mg} / \mathrm{l} 00 \mathrm{~g})$ was found in the fruits which were produced with $2.5 \mathrm{~kg} \mathrm{~B}+6 \mathrm{~kg} \mathrm{Zn/ha} \mathrm{followed} \mathrm{by} 2 \mathrm{~kg} \mathrm{~B}+$ $4 \mathrm{~kg} \mathrm{Zn/ha}(9.16 \mathrm{mg} / \mathrm{l00g})$, which was statistically significant. The lowest ascorbic acid (8.34 $\mathrm{mg} / \mathrm{l} 00 \mathrm{~g})$ was noted without boron and zinc, which was significant from the other treatments (Table 1). Similar trend was also observed regarding this parameter due to the main effect of NPK as was evident in the case of acidity (Table 2). It ranged from 8.64 to $9.77 \mathrm{mg} / 100 \mathrm{~g}$. On the contrary, remarkable variation was observed among the treatment combinations in respect of ascorbic acid content of the fruits. The fruits which were produced with $2.5 \mathrm{~kg}$ $\mathrm{B}+6 \mathrm{~kg} \mathrm{Zn/ha}$ and recommended dose of NPK contained the highest ascorbic acid $(10.95 \mathrm{mg} / 100 \mathrm{~g})$, while it was the lowest $(8.00 \mathrm{mg} / 100 \mathrm{~g})$ when grown without boron, zinc and 50\% less than recommended dose of NPK (Table 3). Dube et al. (2004) opined that ascorbic acid content of fruits improve with zinc sulphate and borax @ 10 and 20 kg/ha, respectively.

Lycopene content: The results of the investigation revealed that lycopene content of the fruits increased with increasing boron and zinc levels (Table 1). The highest lycopene $(97.66 \mu \mathrm{g} / 100 \mathrm{~g})$ was measured in fruits which were produced with $2.5 \mathrm{~kg} \mathrm{~B}+6 \mathrm{~kg} \mathrm{Zn} / \mathrm{ha}$. Besides, the main effect of NPK was also significantly influenced the lycopene content of fruits. It was as low as 67.25 $\mu \mathrm{g} / 100 \mathrm{~g}$ in $50 \%$ less than recommended dose of NPK to as high as 81.25 $\mu \mathrm{g} / 100 \mathrm{~g}$ in recommended dose of NPK (Table 2). On the other hand, the highest 
Table 4. Main effect of boron and zinc on \% marketable fruit of tomato during storage.

\begin{tabular}{|c|c|c|c|c|c|c|c|c|c|}
\hline \multirow{2}{*}{ Treatment } & \multicolumn{8}{|c|}{ \% Marketable fruit at days after storage (DAS) } & \multirow{2}{*}{$\begin{array}{c}\text { Shelf life } \\
\text { (Days) }\end{array}$} \\
\hline & 9 & 12 & 15 & 18 & 21 & 24 & 27 & 30 & \\
\hline $\mathrm{B}_{0} \mathrm{Zn}_{0}$ & 95.04 & 80.37 & 64.03 & 57.22 & 51.83 & 49.93 & 49.00 & 49.00 & 8.00 \\
\hline $\mathrm{B}_{1.5} \mathrm{Zn}_{2}$ & 97.52 & 86.38 & 71.18 & 63.13 & 55.95 & 50.97 & 50.97 & 50.97 & 9.33 \\
\hline $\mathrm{B}_{2} \mathrm{Zn}_{4}$ & 100.00 & 96.45 & 80.82 & 69.23 & 62.31 & 59.33 & 56.18 & 56.18 & 10.33 \\
\hline $\mathrm{B}_{2.5} \mathrm{Zn}_{6}$ & 100.00 & 100.00 & 93.84 & 80.87 & 68.52 & 62.28 & 61.36 & 61.36 & 13.00 \\
\hline LSD (1\%) & 1.521 & 1.52 & 1.16 & 1.14 & 1.54 & 1.51 & 1.16 & 1.98 & 0.55 \\
\hline CV(\%) & 1.18 & 1.27 & 1.12 & 1.28 & 1.94 & 2.08 & 1.59 & 2.65 & 2.49 \\
\hline
\end{tabular}

$\mathrm{B}_{0}=0 \mathrm{~kg} \mathrm{~B} / \mathrm{ha} \quad \mathrm{Zn}_{0}=0 \mathrm{~kg} \mathrm{Zn} / \mathrm{ha}$

$\mathrm{B}_{1.5}=1.5 \mathrm{~kg} \mathrm{~B} / \mathrm{ha} \quad \mathrm{Zn}_{2}=2 \mathrm{~kg} \mathrm{Zn} / \mathrm{ha}$

$\mathrm{B}_{2.0}=2.0 \mathrm{~kg} \mathrm{~B} / \mathrm{ha} \quad \mathrm{Zn}_{4}=4 \mathrm{~kg} \mathrm{Zn} / \mathrm{ha}$

$\mathrm{B}_{2.5}=2.5 \mathrm{~kg} \mathrm{~B} / \mathrm{ha} \quad \mathrm{Zn}_{6}=6 \mathrm{~kg} \mathrm{Zn} / \mathrm{ha}$

Table 5. Main effect of NPK fertilizers on \% marketable fruit of tomato during storage.

\begin{tabular}{|c|c|c|c|c|c|c|c|c|c|}
\hline \multirow{2}{*}{ Treatment } & \multicolumn{8}{|c|}{ \% Marketable fruit at days after storage (DAS) } & \multirow{2}{*}{$\begin{array}{c}\text { Shelf life } \\
\text { (Days) }\end{array}$} \\
\hline & 9 DAS & 12 DAS & 15 DAS & 18 DAS & 21 DAS & 24 DAS & 27 DAS & 30 DAS & \\
\hline $\begin{array}{l}\text { NPK 50\% } \\
<\text { RD }\end{array}$ & 100.00 & 97.56 & 86.16 & 73.98 & 63.36 & 58.09 & 57.47 & 57.47 & 9.25 \\
\hline NPKRD & 100.00 & 92.21 & 77.20 & 67.61 & 61.31 & 58.31 & 57.57 & 57.57 & 12.00 \\
\hline $\begin{array}{l}\text { NPK 50\% } \\
>\text { RD } \\
\end{array}$ & 94.42 & 82.63 & 69.03 & 61.24 & 54.29 & 50.48 & 48.10 & 48.10 & 9.25 \\
\hline LSD (1\%) & 1.32 & 1.32 & 1.00 & 0.99 & 1.33 & 1.31 & 1.00 & 1.26 & 0.48 \\
\hline CV (\%) & 1.18 & 1.27 & 1.12 & 1.28 & 1.94 & 2.08 & 1.59 & 2.65 & 2.49 \\
\hline
\end{tabular}

NPK RD = Recommended dose of NPK fertilizers (Urea $=550 \mathrm{~kg} / \mathrm{ha}, \mathrm{TSP}=450 \mathrm{~kg} / \mathrm{ha}$, and MOP =250 kg/ha) 
Table 6. Combined effect of boron and zinc and NPK fertilizers on \% marketable fruit of tomato during storage.

\begin{tabular}{|c|c|c|c|c|c|c|c|c|}
\hline \multirow{2}{*}{ Treatment } & \multicolumn{8}{|c|}{ \% Marketable fruit at days after storage (DAS) } \\
\hline & 9 & 12 & 15 & 18 & 21 & 24 & 27 & 30 \\
\hline $\mathrm{B}_{0} \mathrm{Zn}_{0} \mathrm{NPK} 50 \%<\mathrm{RD}$ & 100.00 & 90.26 & 75.46 & 63.24 & 57.26 & 54.40 & 54.40 & 54.40 \\
\hline $\mathrm{B}_{0} \mathrm{Zn}_{0} \mathrm{NPK} \mathrm{RD}$ & 100.00 & 83.41 & 58.43 & 56.26 & 51.24 & 51.24 & 50.26 & 50.26 \\
\hline $\mathrm{B}_{0} \mathrm{Zn}_{0} \mathrm{NPK} 50 \%>\mathrm{RD}$ & 85.14 & 67.46 & 58.21 & 52.16 & 47.00 & 44.15 & 42.36 & 42.36 \\
\hline $\mathrm{B}_{1.5} \mathrm{Zn}_{2} \mathrm{NPK} 50 \%<\mathrm{RD}$ & 100.00 & 100.00 & 80.46 & 69.64 & 64.18 & 57.56 & 57.56 & 57.56 \\
\hline $\mathrm{B}_{1.5} \mathrm{Zn}_{2} \mathrm{NPK} \mathrm{RD}$ & 100.00 & 85.43 & 70.26 & 63.48 & 55.42 & 52.36 & 52.36 & 52.36 \\
\hline $\mathrm{B}_{1.5} \mathrm{Zn}_{2}$ NPK $50 \%>\mathrm{RD}$ & 92.56 & 73.72 & 62.82 & 56.27 & 48.26 & 43.00 & 43.00 & 43.00 \\
\hline $\mathrm{B}_{2} \mathrm{Zn}_{4}$ NPK $50 \%<\mathrm{RD}$ & 100.00 & 100.00 & 88.72 & 72.661 & 64.18 & 60.41 & 57.92 & 57.92 \\
\hline $\mathrm{B}_{2} \mathrm{Zn}_{4} \mathrm{NPK} \mathrm{RD}$ & 100.00 & 100.00 & 80.14 & 72.25 & 67.33 & 62.16 & 60.20 & 60.20 \\
\hline $\mathrm{B}_{2.5} \mathrm{Zn}_{4} \mathrm{NPK} 50 \%>\mathrm{RD}$ & 100.00 & 89.36 & 73.60 & 62.78 & 55.42 & 55.42 & 50.44 & 50.44 \\
\hline $\mathrm{B}_{2.5} \mathrm{Zn}_{6} \mathrm{NPK} 50 \%<\mathrm{RD}$ & 100.00 & 100.00 & 100.00 & 90.40 & 67.82 & 60.00 & 60.00 & 60.00 \\
\hline $\mathrm{B}_{2.5} \mathrm{Zn}_{6} \mathrm{NPK} \mathrm{RD}$ & 100.00 & 100.00 & 100.00 & 78.45 & 71.26 & 67.48 & 67.48 & 67.48 \\
\hline $\mathrm{B}_{2.5} \mathrm{Zn}_{6} \mathrm{NPK} 50 \%>\mathrm{RD}$ & 100.00 & 100.00 & 81.52 & 73.78 & 66.48 & 59.36 & 56.62 & 56.62 \\
\hline LSD (1\%) & 2.64 & 2.64 & 2.00 & 1.98 & 2.67 & 2.62 & 2.00 & 3.43 \\
\hline CV (\%) & 1.18 & 1.27 & 1.12 & 1.28 & 1.94 & 2.08 & 1.59 & 2.65 \\
\hline
\end{tabular}


lycopene $(112.00 \mu \mathrm{g} / 100 \mathrm{~g})$ was recorded with $2.5 \mathrm{~kg} \mathrm{~B}+6 \mathrm{~kg} \mathrm{Zn} / \mathrm{ha}$ and $50 \%$ more than recommended dose of NPK (Table 3). But the lowest lycopene (41.00 $\mu \mathrm{g} / 100 \mathrm{~g}$ ) was recorded without boron, zinc and $50 \%$ less than recommended dose of NPK, which was statistically significant from those of the other treatment combinations. Dube et al. (2003) stated that zinc application significantly improved lycopene content.

Chlorophyll-a: The highest chlorophyll-a (35.66 mg/100g) was found in the fruits which were produced with the highest boron and zinc level. NPK also had significant effect in respect of chlorophyll-a content. It varied from 25.00 to $31.50 \mathrm{mg} / 100 \mathrm{~g}$ (Table 2). Remarkable variation was observed among the treatment combinations in respect of chlorophyll-a content of the fruits. It ranged from 16.00 to $41.00 \mathrm{mg} / 100 \mathrm{~g}$. The fruits produced with $2.5 \mathrm{~kg} \mathrm{~B}+6 \mathrm{~kg} \mathrm{Zn} / \mathrm{ha}$ and recommended dose of NPK contained the highest chlorophyll-a. On the other hand, the lowest chlorophyll-a was observed in fruits, which were produced without boron, zinc and 50\% less than recommended dose of NPK (Table 3). Yada et al. (2001) obtained the highest total chlorophyll with the optimum of 7.5 ppm zinc and $1.00 \mathrm{ppm}$ boron. Singh and Singh (2004) opined that zinc application increased chlorophyll content.

Chlorophyll-b: Wide variation was observed among the boron and zinc levels as to the chlorophyll-b content of the fruits. The maximum chlorophyll-b content (48.33 mg/100g) was recorded with $2.5 \mathrm{~kg} \mathrm{~B}+6 \mathrm{~kg} \mathrm{Zn/ha} \mathrm{(Table} \mathrm{1).}$ Chlorophyll- b content of the fruit also differed due to the NPK levels. It was as low as $34.75 \mathrm{mg} / 100 \mathrm{~g}$ in $50 \%$ less than recommended dose of NPK to as high as $43.50 \mathrm{mg} / 100 \mathrm{~g}$ in recommended dose of NPK (Table 2). Combination of boron, zinc and NPK had distinct variation as to the chlorophyll-b content of the fruit. Chlorophyll-b content was increased with the increasing NPK levels upto optimum dose and then decreased. The highest chlorophyll-b content (56.00 $\mathrm{mg} / 100 \mathrm{~g}$ ) was recorded with $2.5 \mathrm{~kg} \mathrm{~B}+6 \mathrm{~kg} \mathrm{Zn/ha}$ and recommended dose of NPK followed by $2 \mathrm{~kg} \mathrm{~B}+4 \mathrm{~kg} \mathrm{Zn/ha}$ and recommended dose of NPK (51.00 $\mathrm{mg} / 100 \mathrm{~g})$. On the other hand, the lowest $(24.00 \mathrm{mg} / \mathrm{l00g})$ was found without boron, zinc and $50 \%$ less than recommended dose of NPK (Table 3).

Boron content: Boron content of the fruits differed significantly due to the boron and zinc levels. Boron content increased with the increasing boron and zinc levels. The maximum boron content (36.33 ppm) was recorded with $2.5 \mathrm{~kg} \mathrm{~B}+6$ $\mathrm{kg} \mathrm{Zn/ha} \mathrm{(Table} \mathrm{1).} \mathrm{On} \mathrm{the} \mathrm{other} \mathrm{hand,} \mathrm{it} \mathrm{was} \mathrm{observed} \mathrm{that} \mathrm{boron} \mathrm{content} \mathrm{also}$ varied as to the NPK levels. It ranged from 30.75 to $34.00 \mathrm{ppm}$ (Table 2). The highest boron content (38.00 ppm) was recorded with $2.5 \mathrm{~kg} \mathrm{~B}+6 \mathrm{~kg} \mathrm{Zn/ha} \mathrm{and}$ $50 \%$ more than recommended dose of NPK followed by $2.5 \mathrm{~kg} \mathrm{~B}+6 \mathrm{~kg} \mathrm{Zn/ha}$ and recommended dose of NPK (37.00 ppm), which was statistically at par (Table 3). The lowest boron content (28.00 ppm) was recorded without boron, 
zinc and 50\% less than recommended dose of NPK. Smit and Combrink (2004) stated that higher boron level increases $\mathrm{Ca}, \mathrm{Mg}, \mathrm{Na}, \mathrm{Zn}$, and B uptake.

Zinc content: Similar trend was also observed as to the zinc content of fruits due to varied levels of boron and zinc as was evident in case of boron content of fruits (Table 1). It was as low as $34.33 \mathrm{ppm}$ without boron and zinc and as high as $45.67 \mathrm{ppm}$ with $2.5 \mathrm{~kg} \mathrm{~B}+6 \mathrm{~kg} \mathrm{Zn/ha}$. Zinc content of the fruits was also significantly affected by the main effect of NPK. It ranged from 38.50 to 42.25 ppm (Table 3). On the contrary, diverse variation was found among the treatment combinations in this respect.

The highest zinc content (49.00 ppm) was found in fruits, which were produced with $2.5 \mathrm{~kg} \mathrm{~B}+6 \mathrm{~kg} \mathrm{Zn} / \mathrm{ha}$ and $50 \%$ more than recommended dose of NPK followed by $2.5 \mathrm{~kg} \mathrm{~B}+6 \mathrm{~kg} \mathrm{Zn/ha} \mathrm{and} \mathrm{recommended} \mathrm{dose} \mathrm{of} \mathrm{NPK} \mathrm{(46.00}$ ppm), whereas it was the lowest (33.00 ppm) without boron, zinc and 50\% less than recommended dose of NPK (Table 5). Dube et al. (2003) obtained the highest zinc content of leaves with the highest rate of zinc.

\section{Storage performance of fruit}

Percent marketable fruit: Data was recorded at 3 days interval upto 30 days after storage. The results of the study revealed that upto 6 days of storage, all fruits were marketable. Boron and zinc levels had significant effect at each stage of storage. At 30 days after storage, the highest marketable fruits (61.36\%) was found when produced with $2.5 \mathrm{~kg} \mathrm{~B}+6 \mathrm{~kg} \mathrm{Zn} / \mathrm{ha}$, while it was the lowest (49.00\%) in without boron and zinc (Table 4). On the other hand, NPK also influenced percent marketable fruits. At 30 days of storage, it ranged from 48.10 to $57.47 \%$ (Table 5). Remarkable variation was found as to the percent marketable fruits among the stage of storage. There was no $100 \%$ marketable fruits left after 15 days of storage. At 30 days after storages, maximum marketable fruit (67.48\%) was recorded from the plants, which were produced with $2.5 \mathrm{~kg} \mathrm{~B}+6 \mathrm{~kg} \mathrm{Zn/ha} \mathrm{and} \mathrm{recommended} \mathrm{dose} \mathrm{of} \mathrm{NPK} \mathrm{(Table} \mathrm{6).} \mathrm{Besides,}$ the fruits which were produced without boron, zinc and 50\% more than recommended dose of NPK performed less marketable fruits (42.36\%). This might be due to boron and zinc improved resistance power against microbial activities.

Shelf life: There had an appreciable variation among the boron and zinc levels as to the shelf life. Shelf life increased with the increasing boron and zinc levels (Table 4). The highest shelf life (13.00 days) was recorded with $2.5 \mathrm{~kg} \mathrm{~B}+6 \mathrm{~kg}$ $\mathrm{Zn} / \mathrm{ha}$ followed by $2 \mathrm{~kg} \mathrm{~B}+4 \mathrm{~kg} \mathrm{Zn} / \mathrm{ha}$ (10.33 days), which was statistically significant. But the fruits which were produced without boron and zinc performed the lowest (8.00 days) shelf life. On the other hand, significant difference was observed among the NPK levels as to the shelf life (Table 5). It 
varied from 9.25 to 12.00 days. Marked variation was noted regarding shelf life due to the combined effect of boron, zinc and NPK (Fig. 1). The highest shelf life (16.00 days) was recorded in fruits produced with $2.5 \mathrm{~kg} \mathrm{~B}+6 \mathrm{~kg} \mathrm{Zn/ha} \mathrm{and}$ recommended dose of NPK followed by $2.5 \mathrm{~kg} \mathrm{~B}+6 \mathrm{~kg} \mathrm{Zn/ha} \mathrm{and} \mathrm{50 \%} \mathrm{more}$ than recommended dose of NPK (12.00 days) which was statistically significant. But the lowest shelf life (7.00 days) was found without boron, zinc and 50\% more than recommended dose (Fig. 1).
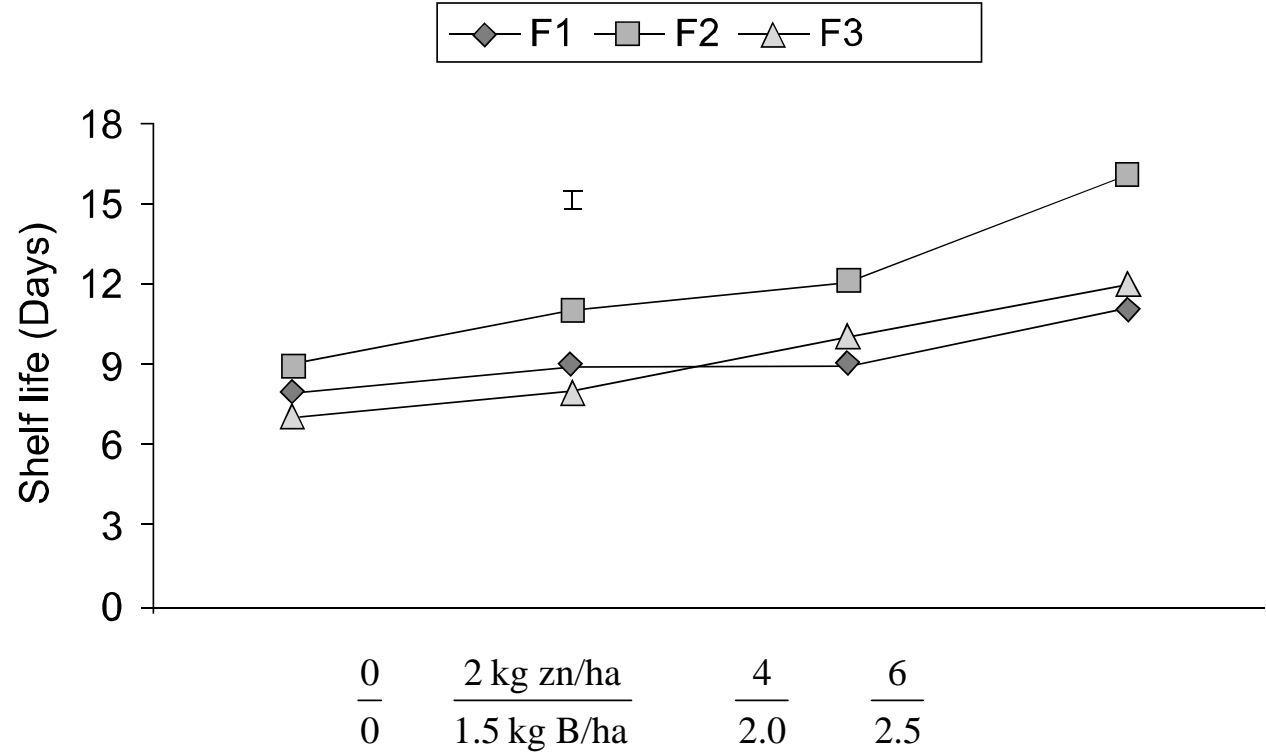

Fig. 1. Effect of boron and zinc at different levels of NPK on shelf life of tomato. The vertical bar indicates LSD at 0.01 level. $\mathrm{F}_{1}=50 \%$ less than recommended dose of $\mathrm{NPK}, \mathrm{F}_{2}=$ Recommended dose of NPK, $\mathrm{F}_{3}=50 \%$ more than recommended dose of NPK.

The reason for higher shelf life might be due to boron and zinc that reduced respiration and transpiration by increasing membrane integrity. Davis et al. (2003) noticed that foliar or soil applied boron increased shelf life.

\section{Conclusion}

From the above discussion, it may be concluded that combination of boron, zinc, and NPK (2.5 kg B $+6 \mathrm{~kg} \mathrm{Zn/ha} \mathrm{and} \mathrm{recommended} \mathrm{dose} \mathrm{of} \mathrm{NPK)} \mathrm{may} \mathrm{be}$ suggested for better quality of tomato.

\section{References}

Balasubramaniam, P., A. K. Mani, P. Duraisamy and M. Kandaswami. 1998. Effect of organic and inorganic nutrients on the yield and uptake of tomato. South Indian Hort. 46(3-6): 143-147. 
BBS. 2007. Year Book of Agricultural Statistics of Bangladesh, Bangladesh Bureau of Statistics, Ministry of Planning, Govt. of the Peoples' Republic of Bangladesh, Dhaka. p.17.

Davis, J. M., D. C. Sanders, P.V. Nelson, L. Lengnick and W.J. Sperry. 2003. Boron improves growth, yield, quality and nutrient content of tomato. J. Amer. Soc. Hort. Sci. 128(3) 44 1-446.

Demoranville, C.J. and K. H. Deubert. 1987. Effect of commercial calcium-boron and manganese-zinc formulations on fruit set of cranberries. J. Hort. Sc. 62: 163-169.

Dube, B. K., S. Pratima and C. Chatterjee. 2003. Effects of zinc on the yield and quality of tomato. Indian J. Hort. 60(1): 59-63.

Dube, B. K., S. Pratima and C. Chatterjee. 2004. Effects of boron and zinc on the yield and quality of tomato. Indian J. Hort. 61(1): 48-52.

Huang, J. S. and S. S. Snapp. 2004. The effect of boron, calcium and surface moisture on shoulder check, a quality defect in fresh market tomato. J. Amer. Soc. Hort. Sci. 129(4): 599-607.

Hunter, A. H. 1980. Soil Fertility Analytical Service in Bangladesh: Consultancy report, BJRI project phase II, BARC, Dhaka, Bangladesh. p.53.

Kalloo. 1985. Tomato. Allied Publishers Private Limited, New Delhi, India. pp. 204-211.

Kumar, P. 2003. Effect of integrated nutrient management on sustainable cabbage and tomato production. Ph.D. Thesis. Department of Vegetable Crops, Dr. YS Parmar University of Horticulture \& Forestry, Nauni, Solan.p.282.

Kurnari, S. 2005. Effect of micronutrient sprays on growth, yield and quality of fruit and seed in tomato. M.Sc. Thesis. Department of Vegetable Crops, Dr YS Parmar University of Horticulture \& Forestry, Nauni, Solan.p. 122.

Magalhaes, J.R. Dc., C.E.W.L. Solwa Dc. and P.H. Monnerat.1980. Levels and methods of boron application in tomatoes. Pesquisa Agropecuria Brasilesia 10 (2): 153-157 [Cited from Hort. Abstr. 50(4): 2031, 19811.

Mondal, M. F. 2000. Production Storage of Fruits (in Bangla). Published by Mrs. Afia Mondal, BAU Campus, Mymensingh-2202. p.312.

Nagata, M., K. Dan and 1. Yamashita. 1992. Simple method for simultaneous determination of chlorophyll and carotenoids in tomato. J. Japan Soc. Hort. Sci. 61(2): 686-687.

Puspha, U. 2004. Influence of graded levels of NPK with and without microbial inoculants on growth, yield and quality of tomato (Lycopersicon esculentum) leaf curl virus resistant lines. M.Sc. Thesis, University of Agricultural Sciences, Bangalore, India. p.121.

Rahayu,Y.S., V. Romheld, F.Bangerth, D. Neilsen, B.Fallahi, G.Neilsen and F.Peryea. 2001. Does zinc nutrition affect calcium disorder of fruits. Acta Hort. 564 :135-143.

Ranganna, S. 1994. Manual of Analisis of Fruit and Vegetable Products. Tata McGrawIIill Publishing Company Limitted, New Delhi, p.1112. 
Shukla, V. and L.B. Naik. 1993. Agro-lechniques for Solanaceous Vegetables. In: Vegetable Crops: Part-I, Advances in Horticulture, Vol. 5, Eds: K.L. Chadha and G. Kalloo, Malhotra Publishing House, New Delhi, India. p.37I

Smit, J. N. and N. J. J. Combrink. 2004. The effect of boron levels in nutrient solutions on fruit production and quality of greenhouse tomatoes. S. Afr. J. Plant Soil. 21(3): 188-19 1.

Yadav, P. V. S., T. Abha, N. K. Sharna and A. Tikko. 2001. Effect of zinc and boron application on growth, flowering and fruiting of tomato. Haryana J. Hort. Sc. 30(1-2): 105-107. 